\title{
Penerapan Pendekatan Saintifik dengan Multimedia untuk Meningkatkan Pembelajaran IPS Tema Panas dan Perpindahannya di Kelas V SD Negeri 1 Kutosari Tahun Ajaran 2018/2019
}

\author{
Mutiara Anggun Puspitasari ${ }^{1}$, M. Chamdani ${ }^{2}$, Wahyudi ${ }^{3}$ \\ 1,2,3Universitas Sebelas Maret \\ mutiaraanggun10@gmail.com
}

\section{Article History}

accepted 01/10/2019

approved 01/11/2019

published 01/12/2019

\begin{abstract}
This study aimed to improve social science learning on the theme of heat and its displacement. This research is classroom action research (CAR) through two cycles. Each cycle consists of planning, implementation, observation, and reflection. The subjects of this study were the fifth grade students of SD Negeri 1 Kutosari, totalling 36 students. The results of the study showed that the application of a scientific approach to multimedia implemented according to the right steps could enhance social science learning on the theme of heat and its displacement.
\end{abstract}

Keywords: scientific, multimedia approach, theme of heat and its displacement

\section{Abstrak}

Tujuan penelitian ini yaitu meningkatkan pembelajaran IPS tema Panas dan Perpindahannya. Penelitian ini merupakan penelitian tindakan kelas (PTK) melalui dua siklus, setiap siklus terdiri dari perencanaan, pelaksanaan, observasi, dan refleksi. Subjek penelitian ini adalah siswa kelas V SD Negeri 1 Kutosari yang berjumlah 36 siswa. Hasil penelitian menunjukkan bahwa penerapan pendekatan saintifik dengan multimedia yang dilaksanakan sesuia langkah yang tepat dapat meningkatkan pembelajaran IPS tema Panas dan Perpindahannya.

Kata kunci: Pendekatan saintifik, multimedia, tema panas dan perpindahannya 


\section{PENDAHULUAN}

Berdasarkan Permendikbud Nomor 67 Tahun 2013 tentang Kerangka Dasar dan Struktur Kurikulum SD/MI, Kurikulum 2013 mulai diberlakukan pada tahun ajaran 2013/2014. Pembelajaran pada Kurikulum 2013 pada jenjang sekolah dasar dilaksanakan secara tematik terpadu. Dalam pembelajaran tematik, muatan mata pelajaran diintegrasikan ke dalam tema. Salah satu mata pelajaran yang terintegrasi ke dalam tema pada Kurikulum 2013 adalah mata pelajaran IImu Pengetahuan Sosial (IPS).

IPS merupakan perpaduan dari berbagai konsep atau materi ilmu-ilmu sosial yang diramu untuk kepentingan program pendidikan dan pembelajaran di sekolah/madrasah (Wahidmurni, 2017:18). Dalam pembelajaran tematik, materi IPS pada siswa kelas rendah terintegrasi dengan mata pelajaran lain, Sedangkan untuk kelas tinggi tidak terintegrasi dengan mata pelajaran apapun. Pembelajaran IPS di kelas tinggi salah satunya berada di kelas $\mathrm{V}$. Pembelajaran IPS di kelas $\mathrm{V}$ terbagi menjadi sembilan tema. Tema satu sampai lima diajarkan di semester satu dan tema enam sampai sembilan diajarkan di semester dua. Untuk tema Panas dan Perpindahannya yang digunakan dalam penelitian ini termasuk ke dalam tema enam yang diajarkan pada semester dua. Sapriya (2014:12) bahwa pembelajaran IPS pada tingkat sekolah bertujuan menyiapkan warga negara yang menguasai pengetahuan (knowledge), keterampilan (skills), sikap dan nilai (attitudes and values). Pentingnya peran IPS dalam kehidupan bermasyarakat menjadikan pembelajaran IPS harus bermakna.

Oleh karena itu, dalam pembelajaran guru perlu melakukan inovasi pembelajaran. Inovasi pembelajaran dapat membuka pola pikir peserta didik bahwa ilmu yang mereka pelajari memiliki kebermaknaan dalam kehidupan sehari-hari (Shoimin, 2014, :20). Inovasi tersebut dilakukan guru khususnya dalam pemilihan pendekatan pembelajaran dan media pembelajaran yang dapat merangsang keaktifan siswa. Menurut Budiyanto, Waluyo, \& Mokhtar (2016: 47) pendekatan saintifik adalah pendekatan dalam proses pembelajaran yang dirancang agar siswa aktif mongkonstruk konsep, hukum, atau prinsip. Dalam Permendikbud Nomor 103 tahun 2014 tentang Standar Proses Pendidikan Dasar dan Menengah uruan proses belajar dalam pendekatan saintifik meliputi: (1) mengamati, (2) menanya, (3) mengumpulkan informasi/mencoba, (4) menalar, (5) mengomunikasikan. Kondisi pembelajaran yang diharapkan setelah pembelajaran dengan pendekatan saintifik diarahkan untuk mendorong siswa mencari tahu dari berbagai sumber melalui observasi, dan bukan hanya diberitahu sehingga pembelajaran menjadi lebih bermakna (Hosnan, 2014:.34).

Berdasarkan hasil wawancara dan observasi di kelas V SD Negeri 1 Kutosari yang dilaksanakan tanggal 2 November 2018 menunjukkan bahwa langkah pendekatan saintifik yang dilakukan guru belum optimal. Masih ditemukan siswa yang pasif selama pembelajaran, siswa yang belum mampu menyampaikan pendapatnya saat diskusi kelompok, saat presentasi siswa masih belum percaya diri, dan perhatian siswa belum semuanya terfokus pada guru sehingga hasil belajar IPS kurang maksimal. Hal ini terlihat dari siswa yang tuntas PTS IPS dengan nilai KKM $=70$ sebanyak 14 dari 36 siswa. Media pembelajaran yang digunakan guru juga kurang optimal, padahal berdasarkan hasil wawancara, siswa kelas $\mathrm{V}$ sangat antusias jika pembelajaran IPS menggunakan media pembelajaran. Salah satu media pembelajaran yang dapat menarik minat siswa dalam pembelajaran adalah multimedia.

Multimedia merupakan kombinasi antara teks, grafik, animasi, suara, dan video (Arsyad, 2015:162). Multimedia yang digunakan dalam pembelajaran jika digunakan dengan tepat akan memberikan kelebihan yaitu: mempermudah siswa dalam belajar, waktu yang digunakan dalam pembelajaran lebih efektif dan efisien, dapat meningkatkan motivasi belajar siswa, dapat meningkatkan prestasi belajar lebih 
optimal (Surasmi, 2016: 597-598). Riyanto \& Gunahardi (2017:57) juga menjelaskan kelebihan dari multimedia yaitu:

(1) the change of model will change the passive to become active learners accordingly, (2) the teacher's role is no more than as a guide, mentor or facilitator in the activities, (3) the students become the center of the learning activities (studentcentered).

Penggunaan multimedia dalam pembelajaran yang dipadukan dengan pendekatan saintifik akan menjadikan pembelajaran menjadi lebih optimal. Hal ini karena dalam pendekatan saintifik siswa dituntut untuk aktif mencari informasi dan penggunaan multimedia dalam pembelajaran dapat memudahkan siswa untuk mendapatkan informasi yang dibutuhkan. Langkah-langkah penerapan pendekatan saintifik yang dipadukan dengan multimedia yaitu: (1) mengamati multimedia, (2) menanya berdasarkan multimedia, (3) mengumpulkan informasi dari multimedia, (4) menalar/mengola informasi, (5) mengomunikasikan.

Rumusan masalah dalam penelitian ini yaitu: (1) bagaimana langkah penerapan pendekatan saintifik dengan multimedia untuk meningkatkan pembelajaran IPS tema Panas dan Perpindahannya di kelas V SD Negeri 1 Kutosari tahun ajaran 2018/2019? (2) apakah penerapan pendekatan saintifik dengan multimedia dapat meningkatkan pembelajaran IPS tema Panas dan Perpindahannya di kelas V SD Negeri 1 Kutosari tahun ajaran 2018/2019? (3) apa kendala dan solusi pada penerapan pendekatan saintifik dengan multimedia untuk meningkatkan pembelajaran IPS tema Panas dan Perpindahannya di kelas V SD Negeri 1 Kutosari tahun ajaran 2018/2019?

Penelitian ini bertujuan (1) mendeskripsikan langkah penerapan pendekatan saintifik dengan multimedia untuk meningkatkan pembelajaran IPS tema Panas dan Perpindahannya di kelas V SD Negeri 1 Kutosari tahun ajaran 2018/2019. (2) meningkatkan pembelajaran IPS tema Panas dan Perpindahannya di kelas V SD Negeri 1 Kutosari tahun ajaran 2018/2019 (3) mendeskripsikan kendala dan solusi penerapan pendekatan saintifik dengan multimedia untuk meningkatkan pembelajaran IPS tema Panas dan Perpindahannya di kelas V SD Negeri 1 Kutosari tahun ajaran 2018/2019.

\section{METODE}

Penelitian ini merupakan penelitian tindakan kelas (PTK) kolaboratif antara guru kelas sebagai pelaksana dengan peneliti dan peneliti. Peneliti menggunakan model penelitian yang dikembangkan oleh Kemmis dan Mc Tagart (Arikunto, 2013:137)

Penelitian ini dilaksanakan pada tahun ajaran 2018/2019 yang bertempat di SD Negeri 1 Kutosari. Subjek penelitian ini adalah siswa kelas V SD Negeri 1 Kutosari yang berjumlah 36 siswa dengan rincian 20 siswa laki-laki dan 16 siswa perempuan serta guru kelas $V$ SD Negeri 1 Kutosari.

Data yang digunakan dalam penelitian ini yaitu data kuantitatif berupa hasil tes belajar siswa dan data kualitatif berupa informasi mengenai pelaksanaan pembelajaran IPS yang menerapkan pendekatan saintifik dengan multimedia.

Sumber data dalam penelitian ini yaitu guru, siswa kelas $V$ dan dokumen PTS IPS siswa. Teknik pengumpulan data yang digunakan dalam penelitian ini menggunakan teknik nontes berupa observasi, wawancara dan dokumentasi. Teknik tes dalam penelitian ini berupa pelaksanaan tes evaluasi yang dilaksanakan untuk mengukur hasil belajar IPS siswa. Data yang sudah terkumpul kemudian dianalisis menggunakan model analisis data menurut Miles dan Huberman yang meliputi tahapan data reduction, data display dan conclusing drawing/verification (Sugiyono, 2015: 337).

Indikator kinerja penelitian baik dari segi proses oleh guru dan siswa maupun hasil pelaksanaan pembela-jaran melalui penerapan pendekatan saintifik dengan 
multimedia sebesar $85 \%$. KKM hasil belajar yang ditargetkan pada penelitian ini yaitu 75. Penelitian dilaksanakan selama 2 siklus yang dilaksanakan selama 6 pertemuan

\section{HASIL DAN PEMBAHASAN}

Penerapan pendekatan saintifik dengan multimedia dilaksanakan sesuai dengan langkah-langkah yaitu: (1) mengamati multimedia, (2) menanya berdasarkan multimedia, (3) mengumpulkan informasi dari multimedia, (4) menalar/mengolah informasi, (5) mengomunikasikan.

Berikut ini merupakan rata-rata hasil observasi penerapan pendekatan saintifik dengan multimedia terhadap guru dan siswa pada setiap siklus:

Tabel 1. Hasil Observasi terhadap Guru dan Siswa

\begin{tabular}{lll}
\hline Siklus & Guru & Siswa \\
\hline I & $86,25 \%$ & $85,81 \%$ \\
II & $89,01 \%$ & $89,05 \%$ \\
\hline
\end{tabular}

Berdasarkan Tabel 1, persentase rata-rata hasil observasi guru pada siklus I yaitu $86,25 \%$. Siklus II meningkat menjadi $89,01 \%$. Persentase rata-rata observasi siswa pada siklus I = 85,81\%, mengalami peningkatan pada siklus II menjadi $89,05 \%$.

Untuk memperkuat hasil penelitian, peneliti melakukan wawancara terhadap guru dan siswa kelas $\mathrm{V}$. Persentase rata-rata hasil wawancara dengan guru pada siklus I sebesar $86,83 \%$. Persentase rata-rata hasil wawancara dengan siswa kelas $\mathrm{V}$ sebesar $85,71 \%$. Persentase rata-rata wawancara terhadap guru dan siswa pada siklus II mengalami peningkatan dari siklus I. Persentase rata-rata wawancara guru pada siklus II sebesar $89,33 \%$. Persentase rata-rata wawancara dengan siswa pada siklus II sebesar $88,82 \%$.

Selain observasi dan wawancara peneliti juga melakukan penilain sikap dan penilaian pengetahuan kepada siswa. Sikap yang dinilai oleh peneliti adalah sikap keaktifan. Berikut ini merupakan tabel hasil dari penilaian sikap keaktifan siswa:

\begin{tabular}{lll}
\multicolumn{3}{c}{ Tabel 2. Hasil Penilaian Keaktifan } \\
\hline Kriteria & Siklus I & Siklus II \\
\hline Sangat baik & $20,3 \%$ & $30,5 \%$ \\
Baik & $66,6 \%$ & $59,2 \%$ \\
Cukup & $12 \%$ & $10,1 \%$ \\
Kurang & $0,9 \%$ & $0 \%$ \\
\hline
\end{tabular}

Berdasarkan tabel tersebut dapat dilihat bahwa terdapat peningkatan persentase sikap keatifan siswa pada setiap siklusnya. Persentase siswa yang mendapatkan nilai sangat baik dan baik pada siklus I sebesar $86,9 \%$ dan meningkat menjadi $89,7 \%$ pada siklus II. Persentase siswa yang mendapatkan nilai cukup pada siklus I sebesar $12 \%$ dan mengalami penurunan menjadi $10,1 \%$ pada siklus II. Siswa yang mendapatkan nilai kurang pada siklus I sebesar $0,9 \%$ dan sudah tidak ditemukan lagi pada siklus II.

Untuk mengukur tingkat pemahaman materi IPS oleh siswa, peneliti melakukan penilaian pengetahuan yang dilakukan dengan memberikan tes evaluasi IPS yang dilakukan setelah pembelajaran. 
Tabel 3. Peningkatan Hasil Belajar Antarsiklus

\begin{tabular}{llll}
\hline \multirow{2}{*}{ Siklus } & & \multicolumn{2}{l}{ Ketuntasan } \\
\cline { 3 - 4 } & Rata & $\begin{array}{l}\text { Belum } \\
\text { Tuntas } \\
(\%)\end{array}$ & $\begin{array}{l}\text { Tuntas } \\
(\%)\end{array}$ \\
\hline I & 82,35 & 12,97 & 87,03 \\
II & 87,96 & 7,47 & 92,53
\end{tabular}

Berdasarkan table di atas, dapat disimpulkan bahwa ketuntasan nilai siswa mengalami peningkatan. Pada siklus I persentase ketuntasan siswa yaitu $87,03 \%$. siklus II persentase ketuntasan yaitu 92,53\%. Kendala dalam pembelajaran yaitu: (1) siswa kesulitan membuat kesimpulan, (2) guru kurang memberikan teguran pada siswa, (3) guru kurang membangkitkan motivasi siswa, (4) tanggapan siswa belum sesuai materi, (5) terbatasnya waktu pembelajaran, (6) tata kalimat siswa dalam memberikan tanggapan kurang tepat. Adapun solusi yang dilakukan yaitu Solusi untuk mengatasi kendala tersebut yaitu: (1) guru membimbing siswa membuat kesimpulan, (2) guru memberikan teguran pada siswa yang gaduh, (3) guru memberikan motivasi ke siswa, (4) guru menjelaskan cara pemberian tanggapan. (5) guru mengefektifkan waktu pembelajaran, (6) guru membimbing siswa menyusun kalimat yang tepat.

\section{SIMPULAN}

Penelitian ini dapat disimpulkan sebagai berikut: Pertama, penerapan pendekatan saintifik dengan multimedia dilaksanakan dengan langkah yang meliputi: (1) mengamati multimedia, (2) menanya berdasarkan multimedia, (3) mengumpulkan informasi dari multimedia, (4) menalar/mengolah informasi, (5) mengomunikasikan. Kedua penerapan pendekatan saintifik dengan multimedia dapat meningkatkan pembelajaran IPS tema panas dan perpindahannya di kelas V, ketiga Ketiga, kendala yang dihadapi peneliti yaitu: (1) siswa kesulitan membuat kesimpulan, (2) guru kurang memberikan teguran pada siswa, (3) guru kurang membangkitkan motivasi siswa, (4) tanggapan siswa belum sesuai materi, (5) terbatasnya waktu pembelajaran, (6) tata kalimat siswa dalam menyampaikan tanggapan kurang tepat. Adapun solusi yang dilakukan yaitu: (1) guru membimbing siswa membuat kesimpulan, (2) guru memberikan teguran pada siswa yang gaduh, (3) guru memberikan motivasi ke siswa, (4) guru menjelaskan cara pemberian tanggapan. (5) guru mengefektifkan waktu pembelajaran, (6) guru membimbing siswa menyusun kalimat yang tepat.

\section{DAFTAR PUSTAKA}

Arikunto, S. (2013). Prosedur Penelitian: Suatu Pendekatan Praktik. Jakarta: Rineka Cipta.

Arsyad,A. (2015). Media Pembelajaran. Jakarta: PT Raja Grafindo Persada.

Budiyanto, M. A. K., Waluyo, L., dan Mokhtar, A. (2016). Implementasi Pendekatan Saintifik dalam Pembelajaran di Pendidikan Dasar di Malang. Proceeding Biology Education Conference: Biology, Science, Enviromental, and Learning, hlm. 46-51, FKIP Universitas Sebelas Maret Surakarta.

Hosnan, M. (2014). Pendekatan Saintifik dan Kontekstual dalam Pembelajaran Abad 21. Bogor: Ghalia Indonesia.

Menteri Pendidikan dan Kebudayaan. (2014).Peraturan Menteri Pendidikan dan Kebudayaan Nomor 103 Tahun 2014 tentang Pembelajaran pada Pendidikan Dasar dan Menengah. Jakarta: Menteri Pendidikan dan Kebudayaan.

Riyanto, W.D dan Gunahardi. (2017). The Effectivenes of Interactive Multimedia in Mathematic Learning, (Utilizing Power Points for Students with Learning Disability). International Journal of Pedagogy and Teacher Education. 1 (1), hlm. 
55-63. Diperoleh pada tanggal 16 Desember 2018 dari https://jurnal.uns.ac.id/ijpte/article/view/84008772.

Sapriya. (2014). Pendidikan IPS: Konsep dan Pembelajarannya. Bandung: PT Remaja Rosdakarya.

Sugiyono. (2015). Metode Penelitian Kuantitatif, Kualitatif, dan R\&D. Bandung: Alfabeta.

Surasmi, W. A. (2016). Pemanfaatan Multimedia untuk Mendukung Kualitas Pembelajaran. Prosiding Temu IImiah Nasional Guru VIII. hlm 593-607, Universitas Terbuka.

Shoimin, A. (2014). 68 Model Pembelajaran Inovatif dalam Kurikulum 2013. Yogyakarta: Ar-Ruzz Media.

Wahidmurni. (2017). Metodologi Pembelajaran IPS: Pengembangan Standar Proses Pembelajaran IPS di Sekolah/Madrasah. Yogyakarta: Ar- Ruzz Media. 